\title{
An empirical investigation of the relationship between the real economy and stock returns for the United States
}

\author{
Andros Gregoriou, John Hunter* and Feng Wu \\ Brunel Business School, Brunel University, Uxbridge, Middlesex, UB8 3PH
}

May 2007

\begin{abstract}
This paper tests for the relationship between excess returns and economic growth rates in the U.S., using a Seemingly Unrelated Regression (SUR) approach. The system includes monthly data for inflation, consumption, narrow money supply and personal disposable income and each equation has up to 24-lagged Autoregressive terms. After removing the four major shocks associated with Black Monday, the Asian Crisis, "9.11" and its anniversary, we cannot find any ARCH behaviour in either the excess returns or the money series. The models are reduced to their parsimonious forms and the inflation and real consumption equations are corrected for $\mathrm{ARCH}$. To make the result more robust we reduce our system to four equations by conditioning on income and testing the remaining equations for stability. The SUR model suggests strong long-run feedback between the financial sector and the real economy firstly through inflation, then consumption while the influence of real money supply appears transitory. Consumption is more sensitive to the economic variables in short and long run as compared with stock market windfalls.
\end{abstract}

Keywords: ARCH, Excess Returns, Long-run Returns, SUR

JEL classifications: C52, E44, G12

* Corresponding author: John Hunter, 01895 266648, e-mail ecstijh@brunel.ac.uk. We would like to thank Menelaos Karanasos for his comments. 


\section{Introduction}

Campbell and Shiller (1987, 1988a, 1988b) have considered how stock returns may form part of a system and interact with other economic variables, in their investigation they utilised the Vector-Autoregressive (VAR) model. More recent papers have revisited these issues, Campbell and Amar (1993) and Lund and Engsted (2002). Two key issues that arise when considering studies based on the VAR is the role and impact of volatility and the capacity to characterise extreme events like stock market crashes in this or any framework. Such analysis has often been restricted to a narrow set of variables that limit the interaction between the economy and the stock market to the behaviour of interest rates and inflation. ${ }^{1}$

In this article, stock market behaviour is characterised by excess returns and excess returns are related to, inflation to capture nominal shocks, a money variable (M1) that captures liquidity, consumption growth to capture the underlying behaviour of the real economy and personal disposable income primarily viewed as a forcing variable for consumption and money.

Initially, a five-variable VAR is estimated using monthly data for the period from January 1983 to December 2004 and this is then reduced to a parsimonious relation from which is extracted long-run behaviour. Excess skewness and kurtosis arise, because of extreme observations, these may be due to underlying volatility, underlying distributions that are non-normal and shocks. Here we cater for shocks using dummies for the extreme events: October 1987, Asian Crisis, 9/11 and its anniversary. Subsequently, we correct for the primary influence of volatility using univariate ARCH and GARCH models. It is suggested by Diebold (1986) that misspecification might arise when ARCH and GARCH models are estimated subject to shocks, here we correct the mean equations for their influence, but this type of correction might also be applied to the variance equations. This precludes finding near integrated $\mathrm{ARCH}$ and $\mathrm{GARCH}$ processes. As the same type of correction does not appear to work for the income equation we decide to estimate a SUR system conditioned on income. The models estimated all satisfy conventional specification tests and the models associated with the SUR system all have stable parameters as a result personal disposable income is seen as super exogenous for the system estimated.

The article is organized as follows. Section 2 provides a brief literature review. Section 3 contains a discussion of data. Section 4 discusses the design of our methodology. Section 5 and Section 6 report results of all single equations and the SUR model, respectively. Section 7 summarizes the main findings.

\section{Models of Asset Prices with Macro Effects}

Conventionally in Finance, Capital Asset Pricing Models have been used to measures the risk of a security by the security's covariance with the stock market return. However, the CAPM has been severely challenged since returns can be predicted from other financial factors, ${ }^{2}$ this has led to the development and testing of various alternative asset pricing specifications, such as the arbitrage pricing theory (APT)(Ross, 1976)

\footnotetext{
${ }^{1}$ Bunn and Redwood (2003) suggest, should macro conditions alter banks tolerance to risk post Basle II, then firms in distress may find it more difficult to roll over debt. Hunter and Isachenkova (2006) find a role for Macroeconomic surprises as drivers of large corporate companies risk of failure.

2 See Fama \& French $(1992,1993)$ for discussion.
} 
that assumes returns are generated by a number of macroeconomic factors. While the Consumption or C-CAPM, measures the risk of a security by the covariance (consumption beta) of its return with per capita consumption. Unfortunately, studies undertaken to test the C-CAPM with data from both U.S. and other countries have been largely negative. ${ }^{3}$ The poor performance of the CAPM and the C-CAPM suggests expected returns are more likely to be driven by more complex stochastic behaviour.

However, it is widely accepted that changes in macroeconomic variables contain important information for market participants, both in the short- and particularly the long horizons. It is hypothesized that investors incorporate such information into their estimates of the appropriate discount rate and the expected dividends flow that in turn affects stock returns ${ }^{4}$. Existing studies model the association between asset prices and other real economic indicators in terms of production rates, productivity, consumption, growth rate of money supply, unemployment, yield spread, and so on. Furthermore, in multivariate setting Vector-Autoregressive (VAR) models have become very popular in the asset pricing. Since When stock returns can be well approximated by log-linear relations then as suggested by Campbell and Shiller (1987,1988a, 1988b), then expected returns, especially in the long run, can be related to other key financial variables such as the dividend growth rate and the price-dividend ratio. Campbell (1991) expanded forward a log-linear present-value model of the stock price and using the VAR as a backward solution, decomposed the variance of stock returns into three variance components: cash flow news, expected return news and covariance of both news. Shiller and Beltratti (1992) and Campbell and Ammer (1993) used the same approach to account for the variance of returns, but here the decomposition was relative to the variance of and covariance with long-term bond returns. The former article cannot provide a theoretical reason for the empirical finding that both U.S. and U.K., stock and bond returns have been positively correlated. However, Campbell and Amar identify additional components such as interest rates and inflation whose absence might explain the U.S. results. They also finds that future excess stock returns can account for most of the variation in excess stock returns, while the variance of excess bond returns is mainly the result of news about future inflation.

Another issue that arises in a univariate context when analysing nominal and sometimes real economic variables is volatility or the presence of ARCH/GARCH behaviour. ${ }^{5}$ The use of these models to analyse time-varying volatility as a risk factor in high frequency returns of financial data has become so widespread that such volatility is now regarded as a proxy for risk and a key parameter in classic derivative pricing models (e.g. Hull, 2002). The co-movement of financial volatilities suggests that it might be more appropriate to consider a multivariate framework. ${ }^{6}$ Here, this seems less pertinent as the

\footnotetext{
${ }^{3}$ For example, see Campbell \& Cochrane (2000), Kocherlakota (1996).

${ }^{4}$ For example, Chen (1991) tests for a group of macroeconomic variables: production growth rate, default premium, term premium, shortterm interest rates, market price-dividend ratio; Chen et al. (1986) tests for an indicator subset: industrial production, spread between long and short-term interest rates, spread between high- and low- grade bonds, aggregate consumption, market portfolios, oil price. Davidson and Froyen (1982) on money supply; Davidson (1982) on inflation and money supply.

${ }^{5}$ See Bollerslev et. al (1992) for a theoretical and empirical review of the ARCH modelling.

${ }^{6}$ For a recent survey of multivariate GARCH models, see Bauwens, Laurent and Rombouts (2003).
} 
excess returns series used are not volatile and this is the focus of our analysis. Also with the combination of VAR and volatility models the curse of dimensionality leads us to concentrate on the mean equation for direct spillovers between the primary variables. ${ }^{7}$ The sample size may induce bias when a large number of parameters are estimated and that may lead to over-fitting, while insufficient lagged variables will cause inconsistency.

The seemingly unrelated regression method estimates a set of linear or non-linear equations with a diagonally imposed covariance matrix of the disturbances across equations. These parameter estimates are used to form a consistent estimate of the covariance matrix of the disturbances, which is then used as a weighting matrix when the model is re-estimated to obtain new values of the parameters. Thus, SURE provides consistent and asymptotically normal estimates of our parameters that may well be asymptotically more efficient than the single equation estimates.

Long horizon time series modelling is sensitive to the data used, so the econometric analysis of the variables are essential before a formal model is designed and this is the focus of the next section.

\section{The Data}

For U.S. stock market returns, close-to-close monthly returns on Standard \& Poor's 500 Composite Index (S\&P 500) are selected. U.S. monthly data for four widely accepted economic determinants of returns are used: Narrow Money (M1), Personal Consumption Expenditure (PCE), Consumer Price Index (CPI) and Personal Dispensable Income (PDI). Due to data availability the PCE PDI data are seasonally adjusted, while M1 and CPI are available without seasonal adjustment. In order to calculate the excess returns, we use 3-month U.S. Treasury Bill yields as the risk-free rate. All the data are collected from DATASTREAM, and converted into real growth rates $\left(g_{i}\right)$ by taking the first difference in their logarithm. ${ }^{8}$ Excess returns on the S\&P500 are calculated as:

$$
R_{t}=\log \left(P_{t} / P_{t-1}\right)-R_{t b i l l 3 m, t}
$$

where $\pi_{t}=\log \left(C P I_{t} / C P I_{t-1}\right)$ and $R_{t}$ and $P_{t}$ are excess returns and the S\&P500 price. While $R_{t b i l l 3 m, t}$ is monthly risk-free rate converted from 3-month U.S. Treasury Bill annual yields.

Diebold (1986) has shown that breaks or shocks in the variance, which are not taken into account before modelling, will appear as ARCH effects when they are included in the sample. In this case, to model the conditional variance as an $\mathrm{ARCH}$ model will be incorrect. It is recommended to divide the sample and test for $\mathrm{ARCH}$ for the sub periods, or use dummies to eliminate those breaks. If no ARCH effects are found in the model with dummies for any of the sub periods, but are found for the whole sample, it is a clear indication of breaks in the unconditional variance and not of ARCH effects. To this purpose, we carefully select the data from 1982:01

\footnotetext{
${ }^{7}$ See Campbell and Ammer (1993) for brief discussion.

${ }^{8}$ All the data are percentiles and are from visiual inspection clearly stationary (for more details see Gregoriou, Hunter and Wu (2006)).
} 
to 2004:12 to avoid both market breaks and potential regime shifts in 1970s, i.e., the shift from fixed to floating exchange rates in 1971, the oil crisis in late 1973 and 1974, and the continuous, significant changes of Capital Gain Tax rates throughout 1970s. Moreover, to ensure comparability of results for different choices of lags, all estimations use the same sample period 1980:01-2004:12 with the first 24 observations reserved for the construction of lagged variables. We also include four shock dummies in the sample period: "Black Monday" in September of 1987, Asian Crisis that also affected the Eastern coast of the U.S. and worldwide markets during August of 1998, terrorist attack on "911" and its anniversary.

As mentioned above, the monthly data have some seasonality or periodicity, and in order to decide the lags of autoregressive models for each series, we need to scrutinize their correlograms. For all series except excess returns, there are 12-month periodic cycles and statistically significant spikes at and around lag 1,12,24,36 with ACF and PACF as well as significant Q-statistics, indicating strong autocorrelations and partial autocorrelations that should be modelled when estimating regressions with these four variables. For returns, there are no apparent periodic fluctuations up to 36 lags and both the ACF and PACF values decline quickly to suggest that there is no "long memory" periodicity. Secondly, Q-Statistics increases sharply around lag 4,15,27 and 31, showing that some "short memory" correlation still plays an important role, but we still decide to include AR terms with the maximum lag of 12 and monthly seasonal dummies in both the return model and other four models, making it easier to see dynamic structures not caused by seasonal adjustments. In particular, due to high kurtosis there are some extreme observations in consumption and income series, and if necessary, we need to either consider the ARCH behaviour or to construct models with longer horizon, say 24 lags (2 years). When the series are stationary, then it should be possible, for any AR model of order $\mathrm{p}$, to find an equivalent MA model with a large enough number, q, of disturbance terms, thus, only AR components are considered in next section.

\section{Empirical Design}

\section{Specification of the single equation}

Let $Y_{t}$ be a vector containing $R_{t}, \pi_{t}$, real consumption growth $\left(g_{c t}\right)$, real money growth $\left(g_{m t}\right)$ and real income growth $\left(g_{i t}\right)$, then the $i^{\text {th }}$ equation with seasonal dummies and four shock dummies is:

$$
y_{i, t}=\mu_{i}+\sum_{m=1}^{11} \beta_{i m} D_{i t}+\sum_{n=1}^{4} \gamma_{i n} D_{s n}+\sum_{j=1}^{5} \sum_{k=1}^{12} \varphi_{i j k} y_{j, t-k}+\varepsilon_{i t}
$$

where $\mu_{i}$ is the mean value of the corresponding variable; $D_{i t}$ are monthly seasonal dummy variables; $D_{s n}$ four shock dummies representing "Black Monday", "Asian Crisis", "911” and anniversary of "911”. And $\beta_{i m}$ and $\varphi_{i j k}$ are the $m^{\text {th }}$ weights of the dummies and the $k^{\text {th }}$ lag coefficient of $y_{j}$ in equation $y_{i}$ equation. ${ }^{9}$ For example:

$$
y_{1, t}=\mu_{1}+\sum_{m=1}^{11} \beta_{1 m} D_{1 t}+\sum_{n=1}^{4} \gamma_{i n} D_{s n}+\sum_{j=2}^{5} \sum_{k=1}^{12} \varphi_{i j k} y_{j, t-k}+\sum_{m=1}^{12} y_{1, t-m}+\varepsilon_{1 t}
$$

\footnotetext{
${ }^{9}$ All the series in first difference form are stationary; details of the tests are available from the authors on request.
} 
is the equation for U.S. excess returns. While the U.S. real consumption growth model is:

$$
y_{3, t}=\mu_{3}+\sum_{m=1}^{11} \beta_{3 m} D_{i t}+\sum_{n=1}^{4} \gamma_{n} D_{s n}+\sum_{j=1, j \neq 3}^{5} \sum_{k=1}^{12} \varphi_{i j k} y_{j, t-k}+\sum_{m=1}^{12} y_{3, t-m}+\varepsilon_{3 t} .
$$

The general modelling process adopted is to estimate overall equations for each variable separately by OLS and subject them to a range of misspecification tests. After dropping insignificant explanatory variables the equation was then subject to a series of misspecification tests, including tests for autocorrelation (an LM-test for up to 12 order autocorrelation), ARCH effect and normality in the residuals, and Chow's parameter stability test. All test results are used to try to improve the individual equations. For example, where the outcome of the ARCH test may suggest the need to consider ARCH behaviour in the equations, and if the residuals of ARCH model are still not normally distributed, then to improve specification we have augmented the model by 12 lagged regressors.

In particular, it is necessary to carry out Chow stability tests for super exogeneity as we wish to consider the extent to which behaviour in the long run can be conditioned..$^{10}$ Normally the five variables are seen as endogenous, but if one of them is super exogenous for the parameters of interest, ${ }^{11}$ then the parameters of the model conditioned on the exogenous variable are invariant to the parameters of the equation associated with the super exogenous variable. As weak exogeneity is a special case of super exogeneity, then inference based on a super exogenous variable is fully efficient. ${ }^{12}$ Weak exogeneity is not readily tested in the short-run, but finding a sub-set of equations in a system that are stable and whose parameters do not vary with the exclusion of variable from the model, would suggest that the model is invariant to the behaviour of that variable. We use recursive coefficients and 1-step Chow tests of parameter stability as tests for super exogeneity. ${ }^{13}$

\section{Correction for volatility}

Using the primary OLS assumptions to estimate the equations separately makes it possible to provide relatively robust corrections for ARCH effects. For one parsimonious single equation, if the residuals are not normally distributed, the specification tests are invalid and when there is correlation in the squared residuals $\mathrm{ARCH}$ may be better to model the dynamic properties of the equation variances.

GARCH $(1,1)$ is used here, as it has been shown by numerous studies that it has a superior fit to high order ARCH models and provides a parsimonious representation of observed volatility. The application of GARCH models to stock market data at the monthly frequency can be found in several studies, for example, in the US case see Akgiray (1989) and for UK, Poon and Taylor (1992). Using (1), for $i^{\text {th }}$ variable the variance equation with a $\operatorname{GARCH}(1,1)$ specification of the variance is:

$$
\sigma_{y_{i t}}^{2}=\omega+\beta \sigma_{y_{i, t-j}}^{2}+\alpha \varepsilon_{y_{i, t-i}}^{2} .
$$

For the higher order moments to exist we require the following conditions to be satisfied by the coefficients:

$$
\alpha_{1}+\beta_{1}<1 \text { and } \omega>0, \alpha_{1} \geq 0, \beta_{1} \geq 0 \text {. }
$$

\footnotetext{
${ }^{10}$ See the discussion of long-run super exogeneity in the introduction to Ericsson and Irons (1994).

${ }^{11}$ For further information on exogeneity, see Engle Hendry and Richard (1983), and Engle and Hendry (1993).

${ }^{12}$ See the discussion of weak and super exogeneity in Engle Hendry and Richard (1983), and Ericsson and Irons (1994).

${ }^{13}$ For further information on testing super exogeneity see Engle and Hendry (1993).
} 
The estimated conditional variances $\hat{\sigma}_{y_{t}}^{2}$ from (4) are used to transform the dependent variable and all the corresponding regressors in the mean equation. Therefore:

$$
\frac{y_{i, t}}{\hat{\sigma}_{y_{i}}}=\mu_{i}\left(\frac{1}{\hat{\sigma}_{y_{i}}}\right)+\sum_{m=1}^{11} \beta_{i m}\left(\frac{D_{i t}}{\hat{\sigma}_{y_{i}}}\right)+\sum_{n=1}^{4} \gamma_{i n}\left(\frac{D_{s n}}{\hat{\sigma}_{y_{i}}}\right)+\sum_{j=1}^{5} \sum_{k=1}^{12} \varphi_{i j k}\left(\frac{y_{j, t-k}}{\hat{\sigma}_{y_{i}}}\right)+\mu_{i t} .
$$

It follows that $\mu_{i t}=\varepsilon_{i t} / \hat{\sigma}_{y_{i}}$ is homoscedastic, non-autocorrelated and normally distributed.

\section{SUR analysis}

Having obtained a satisfactory set of individual OLS equations subject to volatility adjustment, then we control for contemporaneous correlation amongst the equation residuals by estimation via a systems approach. However, the equations may be seemingly unrelated, when $\varepsilon_{i}$ is the $i^{\text {th }}$ equation error and $E\left(\boldsymbol{\varepsilon}_{i}, \boldsymbol{\varepsilon}_{j}^{\prime}\right)=\sigma_{i j} \mathbf{I}$ for all $t, s$, and $i \neq j$. This implies that there are non-zero correlations between contemporaneous disturbances, but zero correlations across all lagged disturbances, while the residuals in any single equation are homoscedastic and nonautocorrelated. This leads us to the SURE.

Although the data are all $\mathrm{I}(0)$, we conduct a long run analysis to extract the long-run inter-relationship between variables in the system and this reveals responses that may be easier to correspond with the theory. The other merit of long-run equations derived from the restricted models that are conditioned on a super exogenous variable is that they ought to be robust to regime shifts associated with the super exogenous variable and invariant to the inclusion of unremarkable variables.

A common approach to testing long-run relationships is through cointegration that can be used to extract long-run behaviour and provide long-run inference (Johansen (1995)). However, the usual approaches to cointegration are optimal when the series are all I(1) ${ }^{14}$ (Engle-Granger (1987)), while in this article the primary relationships due to Finance Theory link returns to consumption growth and inflation, and all variables are generally accepted as being I(0). Further MacKinnon et al. (1999), suggest the critical values of the Johansen test statistic may not be accurate when the cointegration rank is small relative to the dimension of the VAR.

A typical short-run equation for a SUR system in its Polynomial Distributed Lag (PDL) form is given as:

$$
\alpha_{i}(L) y_{i t}=\mu_{i}+\sum_{m=1}^{11} \beta_{i m} D_{i t}+\sum_{n=1}^{4} \gamma_{i n} D_{s n}+\sum_{j=1, j \neq i}^{5} \beta_{i j}(L) y_{j t}+\varepsilon_{i t}
$$

L is the lag operator and (5) in PDL form (Burke and Hunter (2005), Chapter 3) is:

$$
\alpha(L) y_{i, t}=\mu_{i}+\sum_{j=1, j \neq i}^{5} \beta_{i j}(L) y_{j, t}+\varepsilon_{i t}
$$

The long run growth relationship associated with the reduced form (5) is derived by setting $L=1$, removing all remaining dummies and dividing through the resultant equations by $\alpha(1)$. Therefore,

\footnotetext{
${ }^{14}$ Although the Johansen ML approach can also be used with a mixture of $\mathrm{I}(0)$ and $\mathrm{I}(1)$ variables, a VECM including $\mathrm{I}(0)$ series can produce nuisance parameters in the asymptotic distribution of the trace for the cointegration rank, see Wickens (1996) for further discussion on the Johansen ML procedure.
} 


$$
\overline{y_{i}}=\frac{\mu_{i}}{\alpha_{i}(1)}+\sum_{j \neq i}^{5} \frac{\beta_{i j}(1)}{\alpha_{i}(1)} \overline{y_{j}} .
$$

Equation (6) relates long-run growth of $y_{i}$ to long-run growth rates and long-run returns of other variables. ${ }^{15}$ When all the variables are stationary:

$$
\alpha_{i}(1), \beta_{i j}(1) \neq 0 \text {. }
$$

However, the long run is ill-defined when $\alpha(1)$ and $\beta_{j}(1)$ are not significantly different from 0 . A straightforward way to test this is to employ a Wald/F test for the joint hypothesis $\alpha_{i}(1)=0$ and $\beta_{i j}(1)=0$ for all $j$. Equivalently, the sum of coefficients on the lags equals 1 and 0 , respectively.

\section{Parsimonious forms of Single equations corrected for volatility}

On the basis of the p-values for the F-test of joint significance in each equation, the relationships are jointly significant at the $5 \%$ level. However, given the sample size, the models can be improved by removing highly insignificant lagged variables from each equation. Here we use the redundant variables test and its joint Fstatistics/Log likelihood ratio, which allow us to test for the statistical significance of a subset of the included variables. More formally, the test is for whether subsets of variables in an equation all have zero coefficients and might thus be deleted. We also employ Akaike and Schwarz-Bayesian Information Criteria with tests of specification to distinguish between models.

We need to recognise that the unconditional error distribution of consumption and income growth is apparently non-normal with very high values for kurtosis, and these sharp peaks in residuals cannot be removed even when the volatility is removed from the residual variance by application of the ARCH estimator. In response to this we re-specify these models to include in the mean equation another 12 lagged variables, this removes the non-normality from the consumption equation, but it still remains in income equation. Further investigation reveals that leptokurtosis in the income growth equation is caused by spikes in the series that occur from time to time in December and January. This might be linked to shocks to personal income caused large corporate dividend payments. As a result, these extreme observations lead us to carry out the Chow stability tests to determine how sensitive the system is to the behaviour in the income equation, the invariance of the other equations in the model to the structural instability in the income equation suggests that income growth for the parameters of the system presented here can be viewed as being super exogenous. The results in Appendix 4 suggest that the income equation is not stable over the sample period since the recursive residuals lie outside the two standard error band. ${ }^{16}$ Given the parametric limits associated with the data, it would seem difficult to extend the model of real income growth further. So, in the light of the stability tests reported here and to insure that our SUR estimates are robust we condition our system on income growth as a super exogenous variable.

\footnotetext{
${ }^{15}$ See Hendry and Mizon (1978), Hendry (1995) for further discussion.

${ }^{16}$ The recursive Chow tests for the other equations do not reveal instability so they are not reported here, but can be provided on request.
} 
In Table 1 in Appendix 1, we present a summary of OLS estimates for the parsimonious equations modelled without consideration of the conditional variance. ${ }^{17}$ If we look at the results for the return equation in Appendix 2, it is not surprising that changes of income do not have any influence on stock market, since it is widely accepted that people do not primarily invest directly from income, because of the high risk, they prefer to buy real estate or obtain the risk free rate from what is left out of income after consumption. Inflation has direct impact on the stock market since only the 1-period lag is significant. This is consistent with the more casual evidence that stock prices have been impacted on by inflation announcements. This is very appropriate as the U.S. Federal Reserve Bank (the Fed) moved to target inflation in the 1980s.

It is also of interest to investigate the impact, of what are primarily shocks to the stock market, on all four equations. As can be observed from the results in Appendix 2, all four shocks have negative effects on the stock market, but have had no effect on inflation, so we might conclude that stock market shocks will only affect the economy in short term, because they did not influence personal spending. More interestingly, we can see from Appendix 3, that real money supply positively responded to stock disaster and "911", suggesting U.S. monetary policymakers took efforts to increase liquidity in response to these sudden shocks to sterilize their impact on liquidity and the rest of the economy. As "911" was a terrorist attack that had a real impact on US economic life and trade, this shock and its aftermath, contaminated the whole economy. And, as a result, there seems to have been some slight but significant increase in inflation and a decline in growth.

If we now consider model specification, Lagrange multiplier (LM) tests ${ }^{18}$ for up to twelve order ARCH behaviour in the residuals reveals that there are significant $\mathrm{ARCH}$ effects in the equations for inflation and real consumption growth. For excess returns, we cannot find any conditional heteroscedasticity even at $10 \%$ level of significance, so we can assert that there is no apparent ARCH behaviour after removing the large shocks and end of year effects via the seasonal dummies. Table 2 shows the final model specification for the inflation and consumption growth equations controlling for $\mathrm{ARCH}$ effects ${ }^{19}$. Specifically, $\operatorname{GARCH}(1,1)$ seems to best approximate the volatility in both models even though a further 12 lags are added to the consumption and the income equations to handle the non-normality. ${ }^{20}$ The estimates of parameters for the GARCH model of the inflation rate equation are presented in Appendix 5, the coefficients on the AR and MA components respectively of .345 and .626. This implies quite persistent volatility, which may be indicative of un-modelled shocks induced by U.S. government fiscal and Fed monetary policies. However, their sum is still some way from unity.

In order to include allow an ARCH correction to the models in SUR system, we re-estimate the parsimonious OLS equations for inflation and consumption, but with the variables corrected for conditional variance of corresponding GARCH models suggested by (1'). Compared with the results in Table 1, the specifications for the models of inflation and consumption in Table 2 and Table 3 are plausibly similar, the

\footnotetext{
${ }^{17}$ See Appendix 2 and 3 for full OLS estimation results.

${ }^{18}$ Ignoring ARCH effects may result in a loss of efficiency in estimation, for further details, see Engle (1982), Hendry (1995).

${ }^{19}$ See Appendix 5 for full estimation results corrected for volatility.

${ }^{20}$ Given the time-series properties of quarterly and annual consumption and income data, it is not surprising that monthly time series have dynamic effects that go beyond a year (Davidson et al (1978), Muellbauer (1983) and Hendry (1995)).
} 
corresponding mean equations are almost the same, with only some minor changes in the significance levels of coefficients and the higher order lagged terms. That is, those regressors removed or not significant at the 5\% level can be compensated for by the volatility correction or on the basis of the revised inference, regarded as nuisance parameters and discarded. Even so, the dynamic tests in the models that control for ARCH behaviour are preferred to the OLS ones.

Based on the observation of the size of cross product terms in the variance-covariance matrix of residuals, it has been postulated that it is more important to correct for any potential misspecification caused by simultaneity than to correct for autoregressive behaviour of variance of specific equations, and this assumption is tested by SUR estimation in next section.

\section{SUR estimation results}

We now construct a SUR system by adding two parsimonious OLS equations for excess returns and money supply-M1 growth, and two compact OLS estimations adjusted by GARCH variances correction of inflation and consumption growth. The SUR estimation results are reported in Appendix 6. We find that the coefficients are roughly the same as those associated with the single equation estimates by OLS and the goodness of fit statistics are no worse. An advantage of the SUR estimation is that the significance level of the parameters is much better than that of separate equations and these would be considered as more efficient estimates. The finding that the corrections for $\mathrm{ARCH}$ and simultaneity do not affect the estimates would suggest that the estimates are consistent.

The short run behaviour of excess returns is affected by the rest of the economy directly via income growth and to a lesser extent by its own past, as the fifth lag is significant at the 5\% level. Davidson and Froyen (1982) assert that the estimates of the relationship between returns and money growth rates, using monthly data, support the notion that financial markets are efficient, since leverage and credit of capital increase "virtual money". We find support for this proposition in the short run, but this effect decays away. While, consumption growth is impacted on by all macroeconomic variables except income growth that has an indirect influence. Inflation and money growth are affected immediately by the economic activities of the previous month. As may be expected, excess returns are closer to a random walk than the other series.

In order to get long-run equations for U.S. excess returns and the other four macroeconomic variables, we employ (6) and test (7) in a SUR system. After standardisation of the coefficient of the dependent variable in each equation we obtain the following significant long-run equilibrium growth and return equations: ${ }^{21}$

$$
\begin{gathered}
\overline{y_{1}=}-2.451 \overline{y_{2}}+1.321 \overline{y_{3}}-.325 \overline{y_{4}} \\
\quad(.009) \quad(.004) \quad(.192)^{* *} \\
\overline{y_{2}}=- \\
-.0016-.019 \overline{y_{1}}+.429 \overline{y_{3}} \\
(.095)^{* *}(.005) \quad(.001)
\end{gathered}
$$

\footnotetext{
${ }^{21} \mathrm{P}$-values of the Wald test are given in parentheses.
} 


$$
\begin{aligned}
\overline{y_{3}}= & .006+.046 \overline{y_{1}}-.639 \overline{y_{2}}+.124 \overline{y_{4}}+.079 \overline{y_{5}} \\
& (.000)(.000) \quad(.000) \quad(.012) \quad(.046) \\
\overline{y_{4}}= & .130-.068 \overline{y_{1}}-5.195 \overline{y_{2}}+3.241 \overline{y_{3}}-2.048 \overline{y_{5}} \\
& (.014)(.361)^{* *}(.046)
\end{aligned}
$$

where $\overline{y_{i}}$ denote the steady-state value of the corresponding variable. The key determinants of long-run excess returns are inflation and consumption growth, money growth is not significant in the long run even at the $10 \%$ level. The positive effect of consumption growth is quite consistent with the literature on C-CAPM and as this is a significant long-run feature is consistent with returns being driven by stock market fundamentals. Excess returns react negatively to inflation, which is consistent with the observation, that over a significant part of the observed period, the stock market has responded negatively to inflation announcements. This negative relation is also consistent with the conclusions of previous empirical research, i.e. Fama and Schwert (1977), who reject the Fisher's hypothesis that asset returns can be a perfect hedge against inflation. Otherwise, bouts of inflation reduce stock market confidence and nominal returns even adjusted by a risk free rate.

Inflation in the long run, according to our study, is mainly affected by high levels of growth in consumption, suggesting that in the $80 \mathrm{~s}$ and 90 s inflation has been driven by demand in the economy. Interestingly, there is a symmetric response between inflation and excess returns with high returns being associated with a slow down in the rate of inflation in the long run. This also implies a negative relation between the interest and inflation via excess returns.

Thirdly, real consumption growth is the only variable in our models that is significantly affected by all other four variables in both the short run and the long run. As Kocherlakota (1996) asserts, Consumption-based CAPM should be more important than the standard CAPM as far as the integral role of consumption expenditure in whole economy is concerned. However, the importance of every economic indicator is not the same. The smallest coefficient (0.046) of returns in consumption equation suggests that stock market windfalls have the smallest impact on personal spending. It is also indicative of a teasing negative link between interest rates and consumption growth via excess returns. Economists have long theorised that holding gains are even more transitory than windfall income because holding gains may not only fail to recur, but also may be reversed by holding losses. However, even though this wealth effect is small it is highly significant, even in the long run. The largest coefficient (-0.639) is on inflation and as suggested by Deaton (1974), agents may reduce consumption as they confuse relative and absolute price movements. Otherwise, high rates of inflation impair consumers' propensity to spend as they become more frugal. Growth in real money balances, yield a classical response causing consumption to increase. However, from the observed data we do not know whether these responses are symmetric. Hence, the consumer might well react differently when prices fall. It is of interest to note that the coefficient on income growth is small is just significant at $5 \%$, though this is a measure of personal disposable income and not income from the economy as a whole. 
Money growth is affected negatively by excess returns, suggesting that liquidity is drawn out of the real economy when the stock market increases, while that response of the money equation to shocks, suggest that the monetary authorities respond positively to such shocks, to stem the impact of large capital losses. Long-run inflation leads the monetary authorities to reduce the quantity of money in the system. Income growth reduces money, while consumption growth leads to more money. In steady state growth rates are equalized, which leads to an over-all positive impact for growth on money.

We conclude that the real economy as embodied in consumption is complex and this may not be treated well in a single linear or non-linear factor model, such as the C-CAPM. It would also appear that the financial market affects the real economy, but the reverse relationship is less clear.

\section{Conclusions}

The literature on asset-pricing models for CAPM/C-CAPM, VAR and GARCH models that examine the real economy is vast, but due to the complexity of all the different types of effects they have not been analysed conjointly. In this article, using a SUR model, we use a subset of key monthly macroeconomic variables, together with consumption and excess returns in the US, to estimate a group of reduced form equations corrected for the primary impact of the conditional variance. After removing the effects of seasonality and four major shocks associated with Black Monday, Asian Crisis, "9.11" and its anniversary, the parsimonious dynamic models for excess returns and money growth have no ARCH effects. However, the inflation and consumption equations are volatile. This is consistent with the ARCH model of US inflation analysed by Bollerslev (1986) and the observation that consumption growth is volatile relative to income.

The findings in the long run are consistent with the previous work concerning the interaction of macroeconomic variables and excess returns. Essentially, inflation is the biggest component and core indicator of all other variables; nevertheless, it is neglected by standard CAPM. As far as consumption is concerned, the mutual functions of it and other variables are quite complicated, which may be a reason for the poor performance of C-CAPM and the basis of the equity premium puzzle by Mehra and Prescott (1985). Furthermore, the integral role of consumption may encompass other factors that may not be necessary for standard C-CAPM. Recently, some enhanced theories (i.e. limited market participation) and the revised versions of standard C-CAPM framework have been applied and received some support ${ }^{22}$.

In brief, it is felt necessary to have a better understanding of the effect of macroeconomic fundamentals on returns before more complicated forms of asset pricing models ought to be considered. However, from the results presented in this article we find a primary role for consumption in the explanation of excess returns, subject to a role for nominal price shocks when nominal assets do not provide an appropriate hedge. Hence, control of inflation seems to be one key component in stable asset development and consumers making real returns in the long run. Similarly, consumption is responsive to large shocks to stock prices and in a similar manner to inflation. Based on a stable monetary policy framework that is responsive to inflation in the long run

\footnotetext{
${ }^{22}$ See for example, Campbell and Cochrane (1999), Lettau and Ludvigson (2001).
} 
policy can be made conditional on the behaviour of personal income. However, money is still sensitive to the level of demand in the economy as measured by consumption growth.

\section{References}

Akgiray, V. (1989). Conditional heteroscedasticity in time series of stock returns: evidence and forecasts. Journal of Business 62, 55-80.

Bauwens, L., Laurent, S. and Rombouts, J.V.K. (2003). Multivariate GARCH models: a survey. CORE Discussion Paper, forthcoming in Journal of Applied Econometrics

Bollerslev, T. (1987). A conditionally heteroskedastic time series model for speculative prices and rates of return. Review of Economics and Statistics, 69, 542-546.

Bollerslev, T., Chou, R.Y., Kroner, K.F., (1992). ARCH modeling in finance: a review of the theory and empirical evidence. Journal of Econometrics 52, 5 - 59.

Breeden, D. T., Gibbons, M. R. and Litzenberger R. H. (1989), Empirical Test of the Consumption-Oriented CAPM, The Journal of Finance, 44, 231-262

Bunn, P. and Redwood, V. (2003) Company Accounts based Modelling of Business Failure and the Implications for Financial Stability. Bank of England Working Paper No. 210.

Campbell, J.Y.(1991). A variance decomposition for stock returns. Economic Journal 101, 157-179.

Campbell, J. Y. (1993). Intertemporal asset pricing without consumption data. American Economic Review, 83, 487-512.

Campbell, J. Y. (1996). Consumption and the stock market: Interpreting international experience. Swedish Economic Policy Review, 3, 251-299.

Campbell, J. Y., Ammer, J (1993). What Moves the Stock and Bond Market? A Variance Decomposition for Long-turn Asset Returns. Journal of Finance, 48, 3-37.

Campbell, J. Y. \& Cochrane, J. H. (1999). By force of habit: A consumption based explanation of aggregate stock market behaviour. Journal of Political Economy, 107, 205-251.

Campbell, J. Y. and R. J. Shiller (1987), The Cointegration and Test of Present Value models, Journal of Political Economy, 95, 1062-1068.

Campbell, J. Y. and R. J. Shiller (1988a), The dividend-price ratio and expectations of future dividends and discount factors, Review of Financial Studies, 1, 195-228.

Campbell, J. Y. and R. J. Shiller (1988b), Stock prices, earnings, and expected dividends, Journal of Finance, 43, 661-676. Chen, N.-F. (1991). Financial investment opportunities and the macroeconomy. Journal of Finance 46, 529-554.

Chen, N. F., Roll, R., \& Ross, S. A. (1986). Economic forces and the stock market. Journal of Business, 59, 383-403.

Davidson, J.E.H. Hendry, D.F. Srba, F. and Yeo, S. (1978) Econometric modelling of the aggregate time series relationships between consumers expenditure and income in the United Kingdom. Economic Journal, 88, 661-92.

Davidson, Lawrence S.(1982), Inflation Misinformation and Monetary Policy, St. Louis Federal Reserve Bank Review, (June-July 1982), 15-24

Davidson, Lawrence S. and R. T. Froyen (1982), Monetary Policy and Stock Returns, St. Louis Federal Reserve Bank Review, (March 1982), 3-12.

Diebold, F.X. (1986). "Modelling the Persistence of Conditional Variances: A comment." Econometric Reviews, 5, 51-56.

French, K., Schwert, G. W.(1977). Asset returns and inflation. Journal of financial economics, 5 , 115-146

Fama, E.F. \& French, K.R.(1992), The Cross-Section of Expected Stock Returns, The Journal of Finance, Vol. 47, No. 2 , pp. 427-465

Fama, E.F. \& French, K.R.(1993), Common Risk Factors in the Returns on Stocks and Bonds, Journal of Financial Economics, Vol. 33, No. 1, pp. 3-56.

Ferson, W., Kandel, S., \& Stambaugh, R. F. (1987). Tests of the asset pricing with time-varying risk premiums and market betas. Journal of Finance, 42, 201-220.

Gibbons, M., \& Ferson, W. (1985). Tests of asset pricing models with changing expectations and an unobservable market portfolio. Journal of Financial Economics, 11, 217-236.

Hall, R.E. (1978) Stochastic implications of the life cycle-permanent income hypothesis: theory and evidence. Journal of Political Economy, 86, 971-87.

Hansen, L. P., \& Singleton, K. J. (1982). Generalized instrumental variables estimation of nonlinear rational expectations models. Econometrica, 50, 1269-1286.

Hansen, L. P., \& Singleton, K. J. (1983). Stochastic Consumption, Risk Aversion and the Temporal Behavior of Asset Returns. Journal of Political Economy, 91, 249-265.

Hendry, D. F. (1995), Econometrics and Business Cycle Empirics, The Economic Journal, 105, 1622-1636

Hendry, D. F. \& Mizon, G. E. (1978), Serial Correlation as a Convenient Simplification, Not a Nuisance: A Comment on a Study of the Demand for Money by the Bank of England, The Economic Journal, 88, 549-563

Hull, J. C., Option Futures and other derivatives, $6^{\text {th }}$ edition 
Hunter, J and Isachenkova, N. (2006), "Aggregate Economy Risk and Company Failure: An Examination of UK Quoted Firms in the Early 1990s", Journal of Policy Modeling, 28, 911-919

Keynes, J.M., (1936). "The General Theory of Employment, Interest and Money”, Macmillan, London.

Kocherlakota, N. R. (1996). The equity premium: It's still a puzzle. Journal of Economic Literature, 34, 42-71.

MacKinnon, J.G., Hang, A.A. and Michelis, L.(1999), Numerical distribution functions of likelihood ratio tests for cointegration, Journal of Applied Econometrics, 14, 563-77.

Mamaysky, H. (2002), A Model for Pricing Stocks and Bonds with Default Risk," Yale ICF Working Paper, No. 02-13.

Mankiw, N. G., \& Shapiro, M. D. (1986). Risk and return: Consumption beta versus market beta. Review of Economics and Statistics, 68, 452-459.

Mehra, R., \& Prescott, E. C. (1985). The equity premium: A puzzle. Journal of Monetary Economics, 15, $145-161$.

Muellbauer J. (1983) Surprises in the consumption function. Economic Journal, Supplement March , 34-50.

Pesaran, M. H \& Shin, Y \& Smith, R.J. (2001). Bounds Testing Approaches to The Analysis of Level Relationships, Journal of Applied Econometrics, 16, 289-326.

Poon, S.-H.\& Taylor, S.J., (1992). Stock returns and volatility: an empirical study of the UK stock market. Journal of Banking and Finance 16, 37-59.

Said, S.E. \& Dickey, D.A. (1984) Testing for unit roots in autoregressive-moving average models of unknown order, Biometrika, 71, 599-607.

Shiller, R.J., Beltratti, A.E.(1992). Stock Prices and Bond Yields: Can Their Comovements be Explained in Terms of Present Value Models? Journal of Monetary Economics,30, 25-46.

Wickens, M. (1996). Interpreting Cointegrating vectors and common stochastic trends”, Journal of Econometrics, 74, 25571. 


\section{Appendix 1}

Table 1: Summary of the parsimonious lags in OLS Estimation and diagnostic tests

\begin{tabular}{|c|c|c|c|c|c|c|c|c|c|c|c|c|c|c|}
\hline \multirow{2}{*}{$\begin{array}{l}\text { Dependent } \\
\text { Variable }\end{array}$} & \multirow{2}{*}{ Seasonality } & \multirow{2}{*}{$\begin{array}{l}\text { Excess } \\
\text { returns }\end{array}$} & \multirow{2}{*}{ Inflation } & \multirow{2}{*}{$\begin{array}{l}\text { Consumption } \\
\text { growth }\end{array}$} & \multirow{2}{*}{$\begin{array}{l}\text { M1 } \\
\text { growth }\end{array}$} & \multirow{2}{*}{$\begin{array}{l}\text { Income } \\
\text { growth }\end{array}$} & \multicolumn{4}{|c|}{ Additional dummy variables } & \multicolumn{4}{|c|}{ Residual tests } \\
\hline & & & & & & & $\begin{array}{r}\text { Black } \\
\text { Monda }\end{array}$ & $\begin{array}{l}\text { Asian } \\
\text { crisis }\end{array}$ & $\begin{array}{l}\text { “911” } \\
(2001)\end{array}$ & $\begin{array}{c}911 \\
(2002)\end{array}$ & $\begin{array}{l}\text { Corre- } \\
\text { logram }\end{array}$ & $\begin{array}{l}\text { ARCH } \\
\text { LM }\end{array}$ & Kurtosis & Jarque-Bera \\
\hline $\begin{array}{l}\text { Excess } \\
\text { returns }\end{array}$ & 351011 & 5 & 1 & 10 & 811 & - & -0.265 & -0.189 & -0.087 & -0.108 & No & - & 3.00 & $0.042(0.98)$ \\
\hline Inflation & $1-1011^{*}$ & 25 & 1210 & $13-6$ & 2 & $5^{*}$ & - & - & 0.0048 & - & No & $1-5$ & 3.83 & $9.15(0.01)$ \\
\hline $\begin{array}{l}\text { Consumption } \\
\text { growth }\end{array}$ & $1569^{*} 10^{*}$ & 1689 & 18910 & $\begin{array}{c}1-46-1214 \\
20\end{array}$ & 14 & $\begin{array}{c}1416 \\
24\end{array}$ & - & - & - & - & No & $1-12$ & 5.56 & $76.23(0)$ \\
\hline M1 growth & $1-11$ & 159 & 14912 & 178 & $\begin{array}{c}2359 \\
1112\end{array}$ & $\begin{array}{c}2^{*} 34 \\
9^{*}\end{array}$ & 0.0127 & - & 0.0427 & - & No & - & 2.85 & $0.72(0.70)$ \\
\hline $\begin{array}{l}\text { Income } \\
\text { growth }\end{array}$ & 1356910 & $2^{*} 6 * 9$ & $\begin{array}{c}1210 \\
12^{*}\end{array}$ & $\begin{array}{c}1-45^{*} 9^{*} 11 \\
1217^{*} 2023\end{array}$ & 46 & $\begin{array}{c}129-11 \\
13-18\end{array}$ & - & - & -0.0121 & - & No & $1-12$ & 8.52 & $353(0)$ \\
\hline
\end{tabular}

Note: 1$)^{*}:$ Insignificance level at $5 \%$.

2) A maximum of 24 lags of consumption and income growth have been applied for modelling consumption and income growth.

\section{Table 2: Parsimonious GARCH equations correcting for the volatility}

\begin{tabular}{|c|c|c|c|c|c|c|c|c|c|c|c|c|c|c|c|c|}
\hline \multirow{2}{*}{$\begin{array}{l}\text { Dependent } \\
\text { Variable }\end{array}$} & \multirow{2}{*}{$\begin{array}{l}\text { Seasona- } \\
\text { lity }\end{array}$} & \multirow{2}{*}{$\begin{array}{l}\text { Excess } \\
\text { Returns }\end{array}$} & \multirow{2}{*}{ Inflation } & \multirow{2}{*}{$\begin{array}{l}\text { Consumption } \\
\text { growth }\end{array}$} & \multirow{2}{*}{$\begin{array}{c}\text { M1 } \\
\text { growth }\end{array}$} & \multirow{2}{*}{$\begin{array}{l}\text { Income } \\
\text { growth }\end{array}$} & \multicolumn{4}{|c|}{ Additional dummy variables } & \multicolumn{4}{|c|}{ Residual tests } & \multicolumn{2}{|c|}{$\begin{array}{c}\text { ARCH } \\
\text { coefficients }\end{array}$} \\
\hline & & & & & & & $\begin{array}{l}\text { Black } \\
\text { Monday }\end{array}$ & $\begin{array}{l}\text { Asian } \\
\text { Crisis }\end{array}$ & $\begin{array}{l}911 \\
(2001)\end{array}$ & $\begin{array}{l}911 \\
(2002)\end{array}$ & $\begin{array}{l}\text { Corre- } \\
\text { logram }\end{array}$ & $\begin{array}{l}\text { ARCH } \\
\text { LM }\end{array}$ & Kurtosis & $\begin{array}{c}\text { Jarque- } \\
\text { Bera }\end{array}$ & $\mathrm{ARCH}$ & GARCH \\
\hline Inflation & $1-11$ & 25 & 110 & $14-56$ & - & - & - & - & 0.0054 & - & No & none & 3.35 & $\begin{array}{l}1.70 \\
(0.43)\end{array}$ & 0.345 & 0.626 \\
\hline $\begin{array}{l}\text { Consumption } \\
\text { growth }\end{array}$ & 159 & 1689 & $1^{*} 9^{*}$ & 1891020 & 14 & 24 & - & - & - & - & No & none & 3.50 & $\begin{array}{l}2.87 \\
(0.24)\end{array}$ & 0.531 & 0.368 \\
\hline
\end{tabular}

Note: See the note in Table 1.

Table 3 Parsimonious OLS equations correcting for the volatility of the residuals

\begin{tabular}{|c|c|c|c|c|c|c|c|c|c|c|c|c|c|c|}
\hline \multirow{2}{*}{$\begin{array}{l}\text { Dependent } \\
\text { Variable }^{*}\end{array}$} & \multirow{2}{*}{ Seasonality } & \multirow{2}{*}{$\begin{array}{l}\text { Excess } \\
\text { Returns }\end{array}$} & \multirow{2}{*}{ Inflation } & \multirow{2}{*}{$\begin{array}{l}\text { Consumption } \\
\text { growth }\end{array}$} & \multirow{2}{*}{$\begin{array}{l}\text { M1 } \\
\text { growth }\end{array}$} & \multirow{2}{*}{$\begin{array}{l}\text { Income } \\
\text { growth }\end{array}$} & \multicolumn{4}{|c|}{ Additional dummy variables } & \multicolumn{4}{|c|}{ Residual tests } \\
\hline & & & & & & & $\begin{array}{c}\text { Black } \\
\text { Monday }\end{array}$ & $\begin{array}{l}\text { Asian } \\
\text { Crisis }\end{array}$ & $\begin{array}{c}911 \\
(2001)\end{array}$ & $\begin{array}{l}911 \\
(2002)\end{array}$ & Correlogram & $\begin{array}{c}\text { ARCH } \\
\text { LM }\end{array}$ & Kurtosis & Jarque-Bera \\
\hline Inflation & $1-11$ & 25 & 110 & $14-56$ & - & - & - & - & 0.004 & - & No & none & 3.33 & $1.67(0.43)$ \\
\hline $\begin{array}{l}\text { Consumption } \\
\text { growth }\end{array}$ & 159 & $169^{*}$ & 1 & $18910^{* *}$ & 14 & 24 & - & - & -0.015 & - & No & none & 3.28 & $4.37(0.11)$ \\
\hline
\end{tabular}

Note: For the purpose of ARCH correction, all the variables in these equations are all divided by conditional standard deviations. 
Appendix 2: OLS estimation on excess returns, inflation and consumption

\begin{tabular}{|c|c|c|c|c|c|}
\hline \multicolumn{2}{|c|}{ Excess Returns } & \multicolumn{2}{|c|}{ Inflation } & \multicolumn{2}{|c|}{ Consumption } \\
\hline Dependent variables & Coefficient & $\begin{array}{l}\text { Dependent } \\
\text { variables }\end{array}$ & Coefficient. & Dependent variables & Coefficient \\
\hline Black Monday & $-.2649(0)$ & $\mathrm{C}$ & $-.0013(.014)$ & $\mathrm{C}$ & $.0053(0)$ \\
\hline Asian crisis & $-.1894(0)$ & D091101 & $.0048(.003)$ & SEAS(1) & $-.0078(0)$ \\
\hline D091101 & $-.0865(.024)$ & SEAS(1) & $.0046(0)$ & SEAS(5) & $-.0041(.006)$ \\
\hline D091102 & $\begin{array}{l}- \\
.1083(0.005)\end{array}$ & SEAS(2) & $.0047(0)$ & SEAS(6) & $-.0026(.049)$ \\
\hline SEAS(3) & $.0224(.016)$ & $\operatorname{SEAS}(3)$ & $.0036(0)$ & SEAS(9) & $-.0029(.058)^{*}$ \\
\hline SEAS(5) & $.0190(.030)$ & SEAS(4) & $.0028(0)$ & SEAS(10) & $-.0024(.079)^{*}$ \\
\hline SEAS(10) & $.0364(0)$ & SEAS(5) & $.0033(0)$ & Excess returns & \\
\hline SEAS(11) & $.0299(.002)$ & $\operatorname{SEAS}(6)$ & $.0040(0)$ & Lag 1 & $.0201(0)$ \\
\hline Inflation & & $\operatorname{SEAS}(7)$ & $.0022(.002)$ & Lag 6 & $.0122(.020)$ \\
\hline Lag 1 & $\begin{array}{l}- \\
2.0773(.013)\end{array}$ & SEAS(8) & $.0036(0)$ & Lag 8 & $-.0173(.006)$ \\
\hline Consumption growth & & SEAS(9) & $.0041(0)$ & Lag 9 & $.0192(.002)$ \\
\hline Lag 10 & $1.1430(.005)$ & SEAS(10) & $.0030(0)$ & Inflation & \\
\hline M1 growth & & SEAS(11) & $.0008(.071)^{*}$ & Lag 1 & $-.5507(0)$ \\
\hline Lag 8 & $.4853(.004)$ & Excess return & & Lag 8 & $-.3476(.015)$ \\
\hline Lag 11 & $-.7734(0)$ & Lag 2 & $-.0083(0)$ & Lag 9 & $.5304(.007)$ \\
\hline Excess returns & & Lag 5 & $-.0062(.007)$ & Lag 10 & $-.4431(.002)$ \\
\hline Lag 5 & $.1228(.047)$ & Consumption growth & & M1 growth & \\
\hline & & Lag 1 & $.0388(.016)$ & Lag 1 & $.0941(0)$ \\
\hline & & Lag 3 & $.0453(.037)$ & Lag 4 & $-.0683(.004)$ \\
\hline & & Lag 4 & $.0920(.001)$ & Income Growth & \\
\hline & & Lag 5 & $.0782(.004)$ & Lag 1 & $.0910(.021)$ \\
\hline & & Lag 6 & $.0565(.006)$ & $\operatorname{Lag} 4$ & $.0915(.012)$ \\
\hline & & M1 growth & & Lag 16 & $.1002(.007)$ \\
\hline & & Lag 2 & $-.0256(.041)$ & .Lag 24 & $.1100(.002)$ \\
\hline & & Income Growth & & Consumption Growth & \\
\hline & & Lag 5 & $-.0209(.080)^{*}$ & Lag 1 & $-.5832(0)$ \\
\hline & & Inflation & & $\operatorname{Lag} 2$ & $-.3291(0)$ \\
\hline & & Lag 1 & $.5496(0)$ & Lag 3 & $-.1932(.009)$ \\
\hline & & Lag 2 & $-.2031(.001)$ & Lag 4 & $-.1259(.044)$ \\
\hline & & $\operatorname{Lag} 10$ & $.1919(0)$ & Lag 6 & $.1572(.008)$ \\
\hline & & & & Lag 7 & $.2046(.002)$ \\
\hline & & & & $\operatorname{Lag} 8$ & $.3232(0)$ \\
\hline & & & & Lag 9 & $.4006(0)$ \\
\hline & & & & Lag 10 & $.2265(.002)$ \\
\hline & & & & Lag 11 & $.1686(.018)$ \\
\hline & & & & Lag 12 & $.1085(.074)^{*}$ \\
\hline & & & & Lag 14 & $-.1110(.034)$ \\
\hline & & & & Lag 20 & $.1752(.001)$ \\
\hline$R^{2}$ & .303 & $R^{2}$ & .521 & $R^{2}$ & .456 \\
\hline$\overline{R^{2}}$ & .272 & $\overline{R^{2}}$ & .475 & $\overline{R^{2}}$ & .385 \\
\hline D-W: & 2.14 & D-W: & 1.96 & D-W: & 1.98 \\
\hline
\end{tabular}

Note:

1) P-values are given in parenthesis

2) SEAS() is series of monthly seasonal dummy variables

3) *: insignificant level at $5 \%$. 
Appendix 3: OLS estimation on real growth rates of M1 and income

\begin{tabular}{|c|c|c|c|}
\hline \multicolumn{2}{|c|}{ Real M1 Growth } & \multicolumn{2}{|c|}{ Real Income Growth } \\
\hline Dependent variables & Coefficient. & Dependent variables & Coefficient. \\
\hline $\mathrm{C}$ & $.0258(0)$ & $\mathrm{C}$ & $.0052(0)$ \\
\hline Black Monday & $.0127(.036)$ & D091101 & $-.0121(.058)^{*}$ \\
\hline D091101 & $.0427(0)$ & SEAS(1) & $-.0010(0)$ \\
\hline SEAS(1) & $-.0439(0)$ & SEAS(3) & $-.0063(.004)$ \\
\hline SEAS(2) & $-.0425(0)$ & $\operatorname{SEAS}(5)$ & $-.0063(.007)$ \\
\hline SEAS(3) & $-.0155(0)$ & $\operatorname{SEAS}(6)$ & $-.0111(0)$ \\
\hline SEAS(4) & $-.0080(.029)$ & SEAS(9) & $-.0105(0)$ \\
\hline SEAS(5) & $-.0390(0)$ & SEAS(10) & $-.0064(.005)$ \\
\hline $\operatorname{SEAS}(6)$ & $-.0157(0)$ & Excess returns & \\
\hline SEAS(7) & $-.0215(0)$ & Lag 2 & $-.0150(.084)$ \\
\hline SEAS(8) & $-.0290(0)$ & Lag 6 & $-.0160(.064)^{*}$ \\
\hline SEAS(9) & $-.0260(0)$ & Lag 9 & $.0167(0.048)$ \\
\hline SEAS(10) & $-.0212(0)$ & Inflation & \\
\hline SEAS(11) & $-.0113(0)$ & Lag 1 & $-.6735(.001)$ \\
\hline Excess returns & & Lag 2 & $.7139(.001)$ \\
\hline Lag 1 & $.0214(.008)$ & Lag 10 & $-.4343(.005)$ \\
\hline Lag 5 & $-.0161(.046)$ & Lag 12 & $.3313(.052)^{*}$ \\
\hline Lag 9 & $-.0181(.030)$ & Consumption Growth & \\
\hline Inflation & & Lag 1 & $.1387(.083)^{*}$ \\
\hline Lag 1 & $-.6460(.001)$ & Lag 2 & $.1557(.047)$ \\
\hline Lag 4 & $-.4029(.026)$ & Lag 3 & $.3145(0)$ \\
\hline Lag 9 & $-.3840(.030)$ & Lag 4 & $-.1749(.016)$ \\
\hline Lag 12 & $.5416(.002)$ & Lag 5 & $.1161(.126)^{* * *}$ \\
\hline Consumption growth & & Lag 9 & $-.1383(.064)^{*}$ \\
\hline Lag 1 & $.2018(.003)$ & Lag 11 & $.2054(.008)$ \\
\hline Lag 7 & $.1629(.021)$ & Lag 12 & $.1866(.024)$ \\
\hline Lag 8 & $.1806(.011)$ & Lag 17 & $.1329(.058)^{*}$ \\
\hline Income growth & & Lag 20 & $-.1455(.036)$ \\
\hline Lag 2 & $-.0918(.077)$ & Lag 23 & $-.1591(.015)$ \\
\hline Lag 3 & $-.1186(.025)$ & M1 Growth & \\
\hline Lag 4 & $-.1137(.040)$ & Lag 4 & $-.1555(0)$ \\
\hline Lag 9 & $-.0871(.097)$ & Lag 6 & $.0946(.012)$ \\
\hline M1 growth & & Income Growth & \\
\hline Lag 2 & $.1294(.032)$ & Lag 1 & $-.3030(0)$ \\
\hline Lag 3 & $.2018(.001)$ & Lag 2 & $-.1485(.030)$ \\
\hline Lag 5 & $.1632(.006)$ & Lag 9 & $-.1458(.021)$ \\
\hline Lag 9 & $.1613(.006)$ & Lag 10 & $-.1450(.028)$ \\
\hline Lag 11 & $-.1602(.005)$ & Lag 11 & $-.2376(0)$ \\
\hline Lag 12 & $.2960(0)$ & Lag 13 & $-.2168(.001)$ \\
\hline & & Lag 14 & $-.1475(.027)$ \\
\hline & & Lag 15 & $-.1165(.082)^{*}$ \\
\hline & & Lag 16 & $-.1202(.066)^{*}$ \\
\hline & & Lag 17 & $.1192(.070)^{*}$ \\
\hline & & Lag 18 & $.1735(.006)$ \\
\hline$R^{2}$ & .863 & $R^{2}$ & .440 \\
\hline$\overline{R^{2}}$ & .844 & $\overline{R^{2}}$ & .350 \\
\hline D-W: & 1.78 & D-W: & 1.91 \\
\hline
\end{tabular}

Note:

1) See the note in Appendix 2.

2)A maximum of 24 lags of consumption and income growth have been applied for modelling consumption and income growth. 


\section{Appendix 4: Stability test for income growth equation}
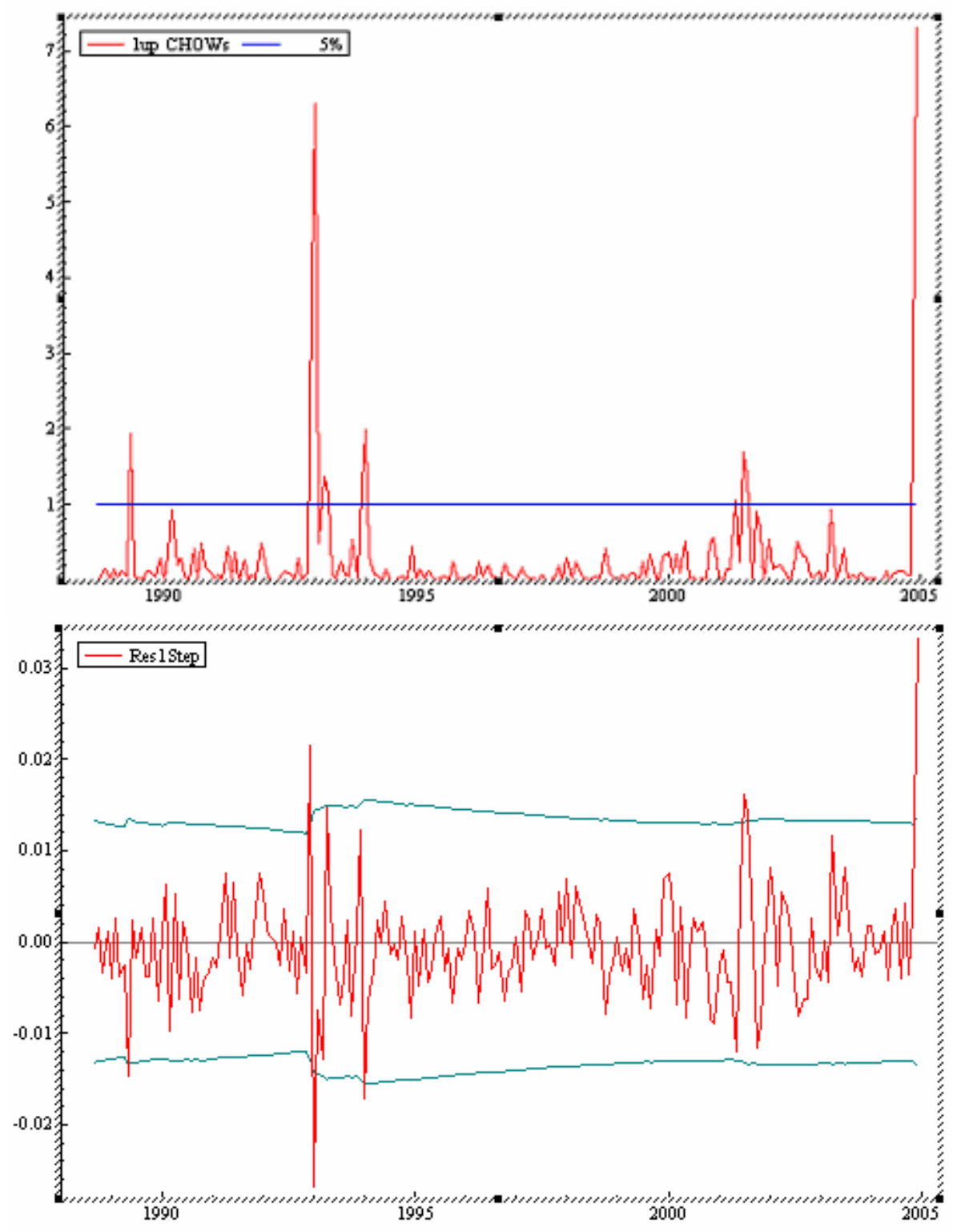


\section{Appendix 5:ARCH correction for residuals of inflation and consumption equations}

\begin{tabular}{|c|c|c|c|c|c|c|c|}
\hline \multicolumn{4}{|c|}{ Inflation } & \multicolumn{4}{|c|}{ Consumption } \\
\hline $\begin{array}{l}\text { Dependent } \\
\text { variables }\end{array}$ & Coefficient. & $\begin{array}{l}\text { Dependent } \\
\text { variables }\end{array}$ & Coefficient & $\begin{array}{l}\text { Dependent } \\
\text { variables }\end{array}$ & Coefficient & $\begin{array}{l}\text { Dependent } \\
\text { variables }\end{array}$ & Coefficient \\
\hline $\mathrm{C}$ & $-.0012(.001)$ & $1 / \hat{\sigma}_{1}$ & $\begin{array}{l}-.0007(.071) \\
*\end{array}$ & $\mathrm{C}$ & $.0034(0)$ & $1 / \hat{\sigma}_{2}$ & $.0046(0)$ \\
\hline 91101 & $.0054(.019)$ & $\frac{9110}{\hat{\sigma}_{1}}$ & $\underset{*}{.0043(0.068)}$ & SEAS(1) & $-.0063(0)$ & $\frac{9110]}{\hat{\sigma}_{2}}$ & $-.0149(0)$ \\
\hline SEAS(1) & $.0043(0)$ & SEAS $(1) *$ & $-.0041(0)$ & SEAS(5) & $-.0041(0)$ & $\operatorname{SEAS}(1)^{+}$ & $-.0067(0)$ \\
\hline SEAS(2) & $.0044(0)$ & $\operatorname{SEAS}(2) *$ & $-.0042(0)$ & SEAS(9) & $-.0028(.002)$ & $\operatorname{SEAS}(5)^{+}$ & $-.0034(.002)$ \\
\hline SEAS(3) & $.0042(0)$ & SEAS (3)* & $-.0043(0)$ & $\begin{array}{l}\text { Excess } \\
\text { returns }\end{array}$ & & $\operatorname{SEAS}(9)^{+}$ & $-.0030(.001)$ \\
\hline SEAS(4) & $.0038(0)$ & SEAS(4)* & $-.0036(0)$ & Lag 1 & $.0277(0)$ & $\frac{\text { Excess return }}{\hat{\sigma}_{2}}$ & \\
\hline SEAS(5) & $.0027(0)$ & $\operatorname{SEAS}(5)^{*}$ & $-.0026(0)$ & Lag 6 & $.0169(.002)$ & Lag 1 & $.0200(0)$ \\
\hline SEAS(6) & $.0032(0)$ & SEAS(6)* & $.0026(0)$ & Lag 8 & $-.0116(.004)$ & Lag 6 & $.0104(.043)$ \\
\hline SEAS(7) & $.0026(0)$ & $\operatorname{SEAS}(7)^{*}$ & $.0022(0)$ & Lag 9 & $.0195(.001)$ & Lag 9 & $.0079(.100)$ \\
\hline SEAS(8) & $.0035(0)$ & $\operatorname{SEAS}(8) *$ & $-.0032(0)$ & Inflation & & $\frac{\text { Inflation }}{\hat{\sigma}_{2}}$ & \\
\hline $\begin{array}{l}\text { SEAS(9) } \\
\text { SEAS(10) }\end{array}$ & $\begin{array}{l}.0041(0) \\
.0032(0)\end{array}$ & $\begin{array}{l}\operatorname{SEAS}(9) * \\
\operatorname{SEAS}(10)^{*}\end{array}$ & $\begin{array}{l}.0036(0) \\
.0030(0)\end{array}$ & $\begin{array}{l}\text { Lag } 1 \\
\text { Lag } 9\end{array}$ & $\begin{array}{l}-.2217(.100)^{*} \\
.1846(.097)^{*}\end{array}$ & $\begin{array}{l}\text { Lag } 1 \\
\frac{\Delta \log (M 1)}{\hat{\sigma}_{2}}\end{array}$ & $-.5026(0)$ \\
\hline $\begin{array}{l}\text { SEAS(11) } \\
\text { Excess } \\
\text { return }\end{array}$ & $.0013(0)$ & $\begin{array}{l}\operatorname{SEAS}(11)^{*} \\
\frac{\text { Excess return }}{\hat{\sigma}_{1}}\end{array}$ & $.0011(.004)$ & $\begin{array}{l}\Delta \log (\mathrm{M} 1) \\
\operatorname{Lag} 1\end{array}$ & $.0987(0)$ & $\begin{array}{l}\text { Lag } 1 \\
\text { Lag } 4\end{array}$ & $\begin{array}{l}.1064(0) \\
-.0419(.027)\end{array}$ \\
\hline Lag 2 & $\begin{array}{l}- \\
.00413(.016)\end{array}$ & Lag 2 & $-.0052(.010)^{*}$ & Lag 4 & $-.0496(.004)$ & $\frac{\Delta \log (\mathrm{I})}{\hat{\sigma}_{2}}$ & \\
\hline $\begin{array}{l}\text { Lag } 5 \\
\Delta \log (\mathrm{C})\end{array}$ & $-.0055(.003)$ & $\begin{array}{l}\text { Lag } 5 \\
\frac{\Delta \log (\mathrm{C})}{\hat{\sigma}_{1}}\end{array}$ & $-.0039(.048)$ & $\begin{array}{l}\Delta \log (\mathrm{I}) \\
\operatorname{Lag} 24\end{array}$ & $.0967(0)$ & $\begin{array}{l}\operatorname{Lag} 24 \\
\frac{\Delta \log (\mathrm{C})}{\hat{\sigma}_{2}}\end{array}$ & $.0693(.043)$ \\
\hline Lag 1 & $.0475(0)$ & Lag 1 & $.0377(.018)$ & $\Delta \log (\mathrm{C})$ & & Lag 1 & $-.2968(0)$ \\
\hline $\begin{array}{l}\text { Lag } 4 \\
\text { Lag } 5 \\
\text { Lag } 6 \\
\text { Inflation }\end{array}$ & $\begin{array}{l}.0549(.001) \\
.0635(.002) \\
.0566(0)\end{array}$ & $\begin{array}{l}\text { Lag } 4 \\
\text { Lag } 5 \\
\text { Lag } 6 \\
\text { Inflation }\end{array}$ & $\begin{array}{l}.0422(.032) \\
.0450(.047) \\
.0490(.008)\end{array}$ & $\begin{array}{l}\text { Lag } 1 \\
\text { Lag } 8 \\
\text { Lag } 9 \\
\text { Lag } 10\end{array}$ & $\begin{array}{l}-.4431(0) \\
.1478(.001) \\
.2659(0) \\
.1274(.015)\end{array}$ & $\begin{array}{l}\text { Lag } 8 \\
\text { Lag } 9 \\
\text { Lag } 10\end{array}$ & $\begin{array}{l}.1369(.031) \\
.1871(.004) \\
.1007(.118)^{\text {** }}\end{array}$ \\
\hline $\begin{array}{l}\text { Lag } 1 \\
\text { Lag } 10\end{array}$ & $\begin{array}{l}.4444(0) \\
.1121(.014)\end{array}$ & \begin{tabular}{l}
\multicolumn{1}{c}{$\hat{\sigma}_{1}$} \\
Lag 1 \\
Lag 10
\end{tabular} & $\begin{array}{l}.3768(0) \\
.1858(.002)\end{array}$ & Lag 20 & $.0846(.013)$ & & \\
\hline $\begin{array}{l}\text { Variance } \\
\text { Equation } \\
\text { C } \\
\text { ARCH(1) } \\
\text { GARCH(1) }\end{array}$ & $\begin{array}{l}2.22 \mathrm{e}-7(0) \\
.3449(0) \\
.6259(0)\end{array}$ & & & $\begin{array}{l}\text { Variance } \\
\text { Equation } \\
\mathrm{C} \\
\text { ARCH(1) } \\
\text { GARCH(1) }\end{array}$ & $\begin{array}{l}3.79 \mathrm{e}-6(0) \\
.5308(0) \\
.3676(0)\end{array}$ & & \\
\hline$R^{2}$ & .466 & $R^{2}$ & .582 & $R^{2}$ & .320 & $R^{2}$ & .420 \\
\hline$\overline{R^{2}}$ & .412 & $\overline{R^{2}}$ & .548 & $\overline{R^{2}}$ & .267 & $\overline{R^{2}}$ & .385 \\
\hline D-W: & 1.78 & D-W: & 1.98 & D-W: & 2.00 & D-W: & 2.02 \\
\hline
\end{tabular}

Note:(1) See the note in Appendix 2, (2) SEAS(i) $)^{*} \operatorname{SEAS}(i) / \hat{\sigma}_{1}$ and SEAS(i $)^{+}=\operatorname{SEAS}(\mathrm{i}) / \hat{\sigma}_{2}$, and (3) $\Delta \log ($.) is growth in $\mathrm{C}=$ consumption, $\mathrm{I}=$ income and $\mathrm{M} 1$ 
Appendix 6 SURE

\begin{tabular}{|c|c|c|c|c|c|c|c|}
\hline \multicolumn{2}{|c|}{ Excess Return } & \multicolumn{2}{|c|}{ Inflation } & \multicolumn{2}{|c|}{ Consumption Growth } & \multicolumn{2}{|c|}{ M1 Growth } \\
\hline $\begin{array}{l}\text { Dependent } \\
\text { variables }\end{array}$ & Coefficient & $\begin{array}{l}\text { Dependent } \\
\text { variables }\end{array}$ & Coefficient & $\begin{array}{l}\text { Dependent } \\
\text { variables }\end{array}$ & Coefficient & $\begin{array}{l}\text { Dependent } \\
\text { variables }\end{array}$ & Coefficient \\
\hline $\begin{array}{l}\text { Black } \\
\text { Monday }\end{array}$ & $-.2682(0)$ & $1 / \hat{\sigma}_{1}$ & $-.0007(.087)^{*}$ & $1 / \hat{\sigma}_{2}$ & $.0046(0)$ & $\mathrm{C}$ & $.0254(0)$ \\
\hline Asian crisis & $-.1925(0)$ & $\frac{\mathrm{D} 09110}{\hat{\sigma}_{1}}$ & $.0040(0.073)^{*}$ & $\frac{\mathrm{D} 09110}{\hat{\sigma}_{2}}$ & $-.0158(0)$ & Black Monday & $.0139(.011)$ \\
\hline D091101 & $-.0900(.015)$ & $\operatorname{SEAS}(1)^{*}$ & $-.0041(0)$ & $\operatorname{SEAS}(1)^{+}$ & $-.0068(0)$ & D091101 & $.0427(0)$ \\
\hline D091102 & $-.1153(0.002)$ & $\operatorname{SEAS}(2)^{*}$ & $-.0042(0)$ & $\operatorname{SEAS}(5)^{+}$ & $-.0034(.001)$ & SEAS(1) & $-.0434(0)$ \\
\hline SEAS(3) & $.0227(.011)$ & $\operatorname{SEAS}(3)^{*}$ & $-.0042(0)$ & $\operatorname{SEAS}(9)^{+}$ & $-.0029(0)$ & SEAS(2) & $-.0421(0)$ \\
\hline $\operatorname{SEAS}(5)$ & $.0192(.024)$ & $\operatorname{SEAS}(4)^{*}$ & $-.0035(0)$ & $\frac{\text { Excess return }}{\hat{\sigma}_{2}}$ & & SEAS(3) & $-.0152(0)$ \\
\hline SEAS(10) & $.0367(0)$ & $\operatorname{SEAS}(5) *$ & $-.0025(0)$ & Lag 1 & $.0204(0)$ & SEAS(4) & $-.0075(.030)$ \\
\hline SEAS(11) & $.0295(.001)$ & $\operatorname{SEAS}(6)^{*}$ & $.0026(0)$ & Lag 6 & $.0084(.078)^{*}$ & SEAS(5) & $-.0385(0)$ \\
\hline Inflation & & $\operatorname{SEAS}(7) *$ & $.0020(0)$ & Lag 9 & $.0092(.038)$ & SEAS(6) & $-.0150(0)$ \\
\hline $\begin{array}{l}\text { Lag } 1 \\
\Delta \log (\mathrm{C})\end{array}$ & $-2.1481(.008)$ & $\begin{array}{l}\operatorname{SEAS}(8)^{*} \\
\operatorname{SEAS}(9)^{*}\end{array}$ & $\begin{array}{l}-.0029(0) \\
.0035(0)\end{array}$ & Lag 1 & $-.5035(0)$ & $\begin{array}{l}\text { SEAS(7) } \\
\text { SEAS(8) }\end{array}$ & $\begin{array}{l}-.0208(0) \\
-.0284(0)\end{array}$ \\
\hline Lag 10 & $1.1580(.003)$ & $\operatorname{SEAS}(10)^{*}$ & $.0028(0)$ & $\frac{\Delta \log (\mathrm{M} 1)}{\hat{\sigma}_{2}}$ & & SEAS(9) & $-.0258(0)$ \\
\hline$\Delta \log (\mathrm{M} 1)$ & & $\operatorname{SEAS}(11)^{*}$ & $.0009(.007)$ & Lag 1 & $.1057(0)$ & SEAS(10) & $-.0203(0)$ \\
\hline Lag 8 & $.4838(.003)$ & $\frac{\text { Excess return }}{\hat{\sigma}_{1}}$ & & Lag 4 & $-.04444(.013)$ & SEAS(11) & $-.0106(.003)$ \\
\hline Lag 11 & $-.7684(0)$ & Lag 2 & $-.0051(.005)$ & $\frac{\Delta \log (\mathrm{I})}{\hat{\sigma}_{2}}$ & & $\begin{array}{l}\text { Excess } \\
\text { returns }\end{array}$ & \\
\hline $\begin{array}{l}\text { Excess } \\
\text { returns }\end{array}$ & & Lag 5 & $-.0031(.081)$ & Lag 24 & $.0647(.040)$ & Lag 1 & $.0213(.003)$ \\
\hline Lag 5 & $.1234(.040)$ & $\Delta \log (\mathrm{C})$ & & $\underline{\Delta \log (\mathrm{C})}$ & & Lag 5 & $-.0176(.017)$ \\
\hline & & $\hat{\sigma}_{1}$ & & $\hat{\sigma}_{2}$ & & & \\
\hline & & Lag 1 & $.0336(.023)$ & Lag 1 & $-.2920(0)$ & Lag 9 & $-.0170(.025)$ \\
\hline & & Lag 4 & $.0463(.009)$ & Lag 8 & $.1435(.015)$ & Inflation & \\
\hline & & Lag 5 & $.0495(.016)$ & Lag 9 & $.2144(.001)$ & Lag 1 & $-.6677(0)$ \\
\hline & & Lag 6 & $.0518(.002)$ & Lag 10 & $.1153(.055)^{*}$ & Lag 4 & $-.4089(.013)$ \\
\hline & & Inflation & & & & Lag 9 & $-.4656(.004)$ \\
\hline & & Lag 1 & $.3863(0)$ & & & Lag 12 & $.5241(.001)$ \\
\hline & & Lag 10 & $.1909(0)$ & & & $\Delta \log (\mathrm{C})$ & \\
\hline & & & & & & Lag 1 & $.2131(.001)$ \\
\hline & & & & & & Lag 7 & $.1499(.019)$ \\
\hline & & & & & & $\begin{array}{l}\operatorname{Lag} 8 \\
\Delta \log (\mathrm{I})\end{array}$ & $.1731(.007)$ \\
\hline & & & & & & Lag 2 & $-.0789(.095)$ \\
\hline & & & & & & Lag 3 & $-.1160(.017)$ \\
\hline & & & & & & Lag 4 & $-.1172(.020)$ \\
\hline & & & & & & Lag 9 & $-.0892(.062)$ \\
\hline & & & & & & $\Delta \log (\mathrm{M} 1)$ & \\
\hline & & & & & & Lag 2 & $.1113(.041)$ \\
\hline & & & & & & Lag 3 & $.2111(0)$ \\
\hline & & & & & & Lag 5 & $.1650(.002)$ \\
\hline & & & & & & Lag 9 & $.1503(.005)$ \\
\hline & & & & & & Lag 11 & $-.1519(.003)$ \\
\hline & & & & & & Lag 12 & $.3167(0)$ \\
\hline$R^{2}$ & .303 & $R^{2}$ & .580 & $R^{2}$ & .419 & $R^{2}$ & .862 \\
\hline$\overline{R^{2}}$ & .271 & $\overline{R^{2}}$ & .546 & $\overline{R^{2}}$ & .384 & $\overline{R^{2}}$ & .843 \\
\hline$\chi^{2}(2)$ & $.045(.98)$ & $\chi^{2}(2)$ & $1.61(.45)$ & $\chi^{2}(2)$ & $4.47(.11)$ & $\chi^{2}(2)$ & $.56(.76)$ \\
\hline
\end{tabular}

Note:(1) See the note in Appendix 2, (2) SEAS(i) ${ }^{*}=\operatorname{SEAS}(i) / \hat{\sigma}_{1}$ and $\operatorname{SEAS}(\mathrm{i})^{+}=\operatorname{SEAS}(\mathrm{i}) / \hat{\sigma}_{2}$, and (3) $\Delta \log ($.$) is growth in$ $\mathrm{C}=$ consumption, $\mathrm{I}=$ income and $\mathrm{M} 1$ 